\title{
PERSEPSI PESANGGEM MENGENAI HUTAN MANGROVE DAN PARTISIPASI PESANGGEM DALAM PENGELOLAAN TAMBAK MANGROVE RAMAH LINGKUNGAN MODEL EMPANG PARIT
}

\author{
Pesanggem Perception about Mangrove Forest and Participation in Environmental Frienldy Mangrove \\ Embankment Empang-Parit Model Management
}

Imam Habibi Elhaq ${ }^{*}$ dan Arif Satria

\begin{abstract}
Departemen Sains Komunikasi dan Pengembangan Masyarakat, Fakultas Ekologi Manusia, IPB
Email :imamhe@yahoo.co.id
\end{abstract}

Diterima 18 Januari 2011 / Diterima 30 Maret 2011

\begin{abstract}
This research was aimed to: (1) analyze perception of the pesanggem about mangrove forest; (2) analyze participation of the pesanggem in an Environmental Friendly Mangrove Embankment Empang-Parit Model Management; (3) analyze the correlation between perception and participation of pesanggem in mangrove embankment management. This research has been conducted by using survey method and supported by qualitative method with in-depth interview and observation. Qualitative method aimed to gain in-depth understanding related to the data which has been obtained from quantitative method. The result shows that most of the pesanggem has positif perception about mangrove forest ecosystem and ecology function of mangrove forest. Most of the pesanggem has negative perception about social-economy function of mangrove forest. Most of the pesanggem has low level participation in planning phase and monitoring phase. Most of the pesanggem has high level participation in implementation phase and benefitted phase.
\end{abstract}

Keywords: perception and participation, pesanggem, stakeholders' interest

\section{PENDAHULUAN}

\section{Latar Belakang}

Luas hutan mangrove yang merupakan sumberdaya pesisir dominan di wilayah Indonesia semakin berkurang. Sekitar tahun 1982-1993 terjadi penurunan luas hutan mangrove di Indonesia dari 4 juta hektar menjadi sekitar 2,5 juta hektar (Dahuri, et. al., 1996). Penurunan luasan mangrove di Indonesia terutama diakibatkan oleh kegiatan konversi mangrove menjadi pertambakan (Anonymous, 2000).

Sementara itu tidak dapat dipungkiri bahwa pertumbuhan penduduk yang semakin pesat menyebabkan persaingan manusia dalam memperoleh kebutuhan hidup mengingat faktor penyebab lain juga mendukung seperti kondisi sosial ekonomi masyarakat pesisir yang relatif masih lemah dan persepsi yang salah tentang hutan mangrove. Konversi mangrove menjadi pertambakan merupakan salah satu jalan pintas yang dilakukan masyarakat untuk memperoleh penghasilan yang besar. Hasil penelitian Witjaksono (2002) di pesisir Teluk Kendari menyatakan bahwa konversi mangrove terutama untuk pertanian serta pertambakan udang dan ikan memiliki keuntungan ekonomi yang jauh lebih besar dibandingkan pemanfaatan mangrove itu sendiri.

Perum Perhutani memiliki sistem pengelolaan tambak mangrove ramah lingkungan model empang-paritf dimana dapat mengakomodir manfaat ekonomi dan ekologi mangrove. Pesanggem (petani tambak) yang tergabung dalam LMDH Mina Wana Lestari bekerjasama dengan Perum Perhutani melalui PHBM Plus menerapkan sistem pengelolaan tambak mangrove di Desa Sedari, Kecamatan Cibuaya, Kabupaten Karawang. Namun, masalah yang terjadi adalah partisipasi pesanggem yang kurang dalam pengelolaan tambak mangrove.

\section{Tujuan Penelitian}

Hutan mangrove cenderung masih dipersepsikan salah karena hutan mangrove sering diklasifikasikan sebagai lahan kosong yang tidak memiliki manfaat sehingga lebih baik dikonversi menjadi pertambakan (Murdiyanto, 2003). Oleh karena itu, penelitian ini ingin mengetahui: (1) persepsi pesanggem mengenai hutan mangrove; (2) partisipasi pesanggem dalam pengelolaan tambak mangrove ramah lingkungan model empang parit; (3) hubungan antara persepsi pesanggem mengenai hutan mangrove dengan partisipasi pesanggem dalam pengelolaan tambak mangrove ramah lingkungan model empang parit.

\section{Kegunaan Penelitian}

Penelitian ini diharapkan dapat memberi manfaat bagi pihak akademisi, pemerintah, dan masyarakat untuk menambah informasi sekaligus dapat dijadikan sebagai salah satu bahan bagi penulisan ilmiah terkait dengan persepsi dan partisipasi. 


\section{PENDEKATAN TEORITIS}

\section{Tinjauan Pustaka}

\section{Persepsi}

Definisi persepsi secara sempit adalah penglihatan, bagaimana cara seseorang melihat sesuatu, sedangkan dalam arti luas adalah pandangan atau pengertian, yaitu bagaimana seseorang memandang atau mengartikan sesuatu (Leavitt, 1978). Persepsi berupa proses penggabungan stimulus sederhana (sensasi) yang diterima oleh panca indera manusia sehingga stimulus-stimulus tersebut memberikan makna tertentu bagi manusia (Atkinson et. al., 1983). Zimbardo (1975) mengemukakan bahwa persepsi memberikan suatu makna terhadap hal-hal dan persepsi membuat suatu arahan dalam perilaku orang. Tanpa proses organisasi pada persepsi, kita tidak akan melihat objek, ruang, kejadian-kejadian, gerakan, orang, atau hubungan-hubungan, dan akan mengarahkan kita pada suatu dunia yang tidak bermakna, sensasi-sensasi yang acak.

\section{Mangrove}

Mangrove merupakan suatu ekosistem yang kompleks. Mangrove terdiri dari berbagai spesies tanaman (pada sebagian besar daerah di Indonesia didominasi oleh Rhizophora spp. dan Avicennia spp.) yang memiliki sifat khusus yaitu dapat beradaptasi tumbuh pada air asin (laut), fauna, dan organisme lain (seperti jamur dan mikroorganisme) beserta komponen abiotik (seperti udara, air, tanah) dimana satu sama lain berinteraksi membentuk suatu kesatuan yang memiliki habitat di perbatasan antara wilayah daratan dan lautan (pesisir) sehingga dipengaruhi oleh pasang surut air laut (IUCN, 1993; Nybakken, 1992; Murdiyanto, 2003).

\section{Fungsi Mangrove}

Fungsi Ekologi Mangrove, yaitu: (1) Melindungi garis pantai dari erosi, gelombang laut, dan angin topan; (2) Mempercepat pembentukan tanah; (3) Mengendalikan banjir; (4) Menstabilkan tanah dengan menangkap dan memerangkap endapan material dari darat yang terbawa air sungai ke laut; (5) Sebagai plasma nutfah dan habitat berbagai organisme lain; (6) Feeding ground, nursery ground, spawning ground, berbagai hewan terutama larva ikan dan udang. Fungsi sosial ekonomi mangrove, yaitu: (1) Hasil kayu-kayu bernilai ekonomi seperti untuk kayu bangunan dan tannin; (2) Bahan baku pembuatan kertas; (3) Sarana rekreasi; (4) Tempat pemijahan ikan dan udang (Cooper, Harrison, dan Ramm., 1995 dalam Murdiyanto, 2003) dan (Haryadi, 1995)

\section{Partisipasi}

Partisipasi adalah keikutsertaan setiap pihak yang terlibat dalam setiap tahapan kegiatan pembangunan. Cohen dan Uphoff (1977) dalam Makmur (2005) membagi partisipasi ke dalam beberapa tahapan, yaitu: (1) Tahap pengambilan keputusan; (2) Tahap pelaksanaan; (3) Tahap monitoring; (4) Tahap menikmati hasil.

\section{Hubungan Persepsi dan Partisipasi}

Susiatik (1998), Haryanto (2003), Zulfarina (2003), Erwina (2005), dan Kholiq (2009) mengemukakan dalam penelitiannya bahwa persepsi masyarakat berhubungan positif dengan tingkat partisipasinya. Namun, berbeda halnya dengan penelitian Amrijono (1993), hasil penelitiannya menunjukkan bahwa persepsi dan sikap masyarakat dalam menanggapi keberadaan taman lingkungan berkorelasi negatif pada tumbuhnya partisipasi masyarakat untuk memanfaatkan lingkungan. Hal ini menurutnya karena ada variabel luar yang tidak ikut diteliti namun berpengaruh pada partisipasi masyarakat tersebut. Oleh karena itu, penelitian tentang hubungan persepsi dan partisipasi masih perlu dilakukan untuk melihat sejauh mana kedua konsep ini berhubungan.

\section{Kerangka Pemikiran}

\section{Kerangka Pemikiran}

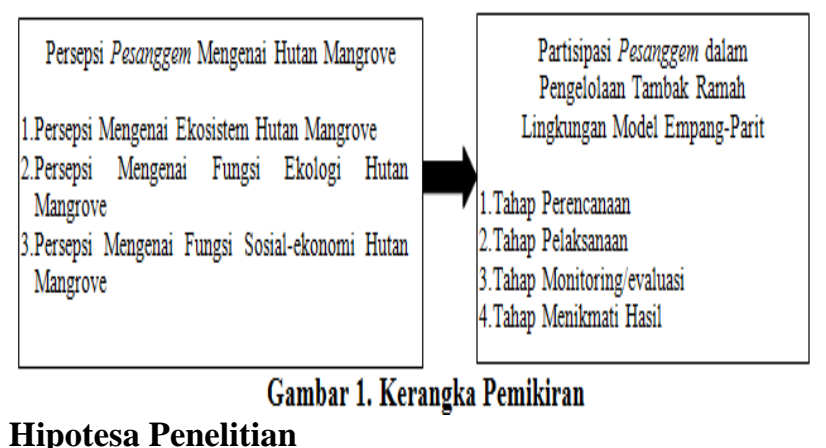

Penelitian ini memiliki hipotesis:

Terdapat hubungan yang signifikan antara persepsi pesanggem mengenai hutan mangrove dengan partisipasi pesanggem dalam pengelolaan tambak ramah lingkungan model empang-parit.

\section{PENDEKATAN LAPANGAN}

\section{Metode Penelitian}

Penelitian ini menggunakan metode survey. Singarimbun dan Effendi (1989) mendefinisikan penelitian survei, yaitu penelitian dimana informasi dikumpulkan dari responden dengan menggunakan kuesioner. Penelitian survei dibatasi pada penelitian yang datanya dikumpulkan dari sampel atau populasi untuk mewakili seluruh populasi. Penelitian survei dipilih dengan harapan dapat mendeskripsikan populasi LMDH "Mina Wana Lestari" dengan sampel yang dipilih, mengemukakan bagaimana persepsi mereka mengenai hutan mangrove, mengemukakan bagaimana partisipasi mereka dalam pengelolaan tambak ramah lingkungan model empangparit, serta melihat hubungan korelasi antara persepsi dengan partisipasi.

\section{Lokasi dan Waktu Penelitian}

Penelitian ini dilakukan di Desa Sedari, Kecamatan Cibuaya, Kabupaten Karawang, pada bulan Juni-Juli 2010.

\section{Teknik Penentuan Responden}

Populasi dalam penelitian ini adalah pesanggem yang didefinisikan sebagai anggota LMDH Mina Wana Lestari KRPH Cibuaya yang berasal dari Desa Sedari dan mengelola secara langsung tambaknya (status bukan

98 Elhaq, Imam Habibi. et. al. Persepsi Pesanggem Mengenai Hutan Mangrove dan Partisipasi Pesanggem dalam Pengelolaan Tambak Mangrove Ramah Lingkungan Model Empang Parit. 
buruh tambak). Sampel adalah 70 orang yang masih mungkin diakses oleh Peneliti dari 80 orang pesanggem.

Informan yang dipilh dalam penelitian ini adalah Asisten Perhutani (Asper) BKPH Cikiong, Ketua LMDH "Mina Wana Lestari", serta tokoh masyarakat Desa Sedari. Namun, tidak menutup kemungkinan beberapa orang dari pihak masyarakat dan Perum Perhutani juga dimintai keterangan berhubungan dengan penelitian. Informan ini diperlukan sebagai pemberi informasi tambahan berkaitan dengan penelitian.

\section{Teknik Pengumpulan dan Analisis Data}

Data yang dikumpukan berupa data primer dan sekunder. Data primer diperoleh dari hasil jawaban responden pada kuesioner. Sementara itu, data sekunder didapatkan dari Pemerintah Desa Sedari dan Perum Perhutani. Selain menggunakan kuesioner, dignakan juga wawancara tidak terstruktur untuk mendapatkan informasi lebih dalam.

Teknik analisis data yang digunakan dalam penelitian ini adalah analisis deskriptif dan analisis korelasi. Analisis deskriptif (analisis univariate) sebagai analisis mengetahui karakteristik setiap variabel pada sampel penelitian. Analisis korelasi dibutuhkan untuk melihat hubungan korelasi antara variabel yang diteliti. Karena tipe data dari masing-masing variabel penelitian adalah data ordinal, maka analisa korelasi yang digunakan adalah rank spearman.

\section{GAMBARAN UMUM LOKASI PENELITIAN}

\section{Keadaan Wilayah}

Desa Sedari merupakan salah satu desa di Kecamatan Cibuaya, Kabupaten Karawang. Luas wilayah Desa Sedari adalah 3.899,5 hektar (Ha). Batas wilayah Desa Sedari sebelah Utara adalah Laut Jawa, sebelah Selatan adalah Desa Kalidung Jaya dan Tambak Sumur, sebelah Timur adalah Desa Cemara Jaya, dan sebelah Barat adalah Desa Tambak Sumur.

\section{Kondisi Geografis Desa}

Wilayah Desa Sedari memiliki topografi dataran rendah, tepi pantai/pesisir, dan bentangan sungai. Tanahnya sebagian besar berwarna hitam dengan tekstur lempungan. Iklim di Desa Sedari termasuk iklim kering dengan curah hujan $0,5 \mathrm{~mm}$, jumlah bulan hujan adalah 2 bulan dengan suhu rata-rata harian $25^{\circ} \mathrm{C}$.

\section{Kondisi Demografis Desa}

Jumlah penduduk Desa Sedari pada tahun 2009 adalah 4523 orang dengan komposisi penduduk laki-laki sebanyak 2.338 orang dan penduduk perempuan sebanyak 2.185 orang. Jumlah Kepala Keluarga (KK) di Desa Sedari pada tahun 2009 sebanyak 1321 KK. Kepadatan penduduk Desa Sedari pada Tahun 2009 adalah 116 orang $/ \mathrm{km}^{2}$. Mata pencaharian utama penduduk Desa Sedari adalah sebagai adalah buruh tambak dan petani tambak.

\section{HASIL PENELITIAN}

\section{Persepsi Mengenai Ekosistem Hutan Mangrove}

Sebagian besar pesanggem memiliki persepsi positif mengenai ekosistem hutan mangrove. Sebesar 97,14 persen (68 orang) pesanggem memiliki persepsi positif mengenai ekosistem hutan mangrove. Sementara itu, hanya sebesar 2,86 persen ( 2 orang) saja yang memiliki persepsi negatif mengenai ekosistem hutan mangrove. Sebagian besar pesanggem memang telah mengenal baik ekosistem hutan mangrove yang telah menjadi lingkungan mereka selama bertahun-tahun. Mereka mengetahui kondisi fisik ekosistem hutan mangrove karena sehari-hari berinteraksi dengan hutan mangrove. Selain itu, semua nilai rataan indikator persepsi mengenai ekosistem hutan mangrove juga tergolong tinggi.

\section{Persepsi Mengenai Fungsi Ekologi Hutan Mangrove}

Sebagian besar pesanggem memiliki persepsi positif mengenai fungsi ekologi hutan mangrove. Sebesar 97,14 persen (68 orang) pesanggem memiliki persepsi positif mengenai fungsi ekologi hutan mangrove. Sementara itu, hanya sebesar 2,86 persen ( 2 orang) pesanggem yang memiliki persepsi negatif mengenai fungsi ekologi hutan mangrove. Hal ini karena pesanggem merasakan manfaat dari adanya hutan mangrove di sekitar mereka yang dapat menciptakan iklim mikro dan mencegah dari bencana alam seperti banjir, tsunami, angin topan, dan abrasi pantai. Selain itu, semua nilai rataan indikator persepsi mengenai fungsi ekologi hutan mangrove juga tergolong tinggi.

\section{Persepsi Mengenai Fungsi Sosial Ekonomi Hutan Mangrove}

Sebagian besar pesanggem memiliki persepsi negatif mengenai fungsi sosial-ekonomi hutan mangrove. Sebesar 74,29 persen (52 orang) pesanggem memiliki persepsi negatif mengenai fungsi sosial-ekonomi hutan mangrove. Sementara itu, sebesar 25,71 persen (18 orang) pesanggem memiliki persepsi positif mengenai fungsi sosial-ekonomi hutan mangrove. Hal ini karena pesanggem belum memahami dengan benar fungsi sosialekonomi hutan mangrove atau memang tidak ditemukan teknologi yang memadai di wilayah Desa Sedari agar mendapatkan keuntungan sosial-ekonomi yang maksimal dari hutan mangrove. Selama ini kayu dari hutan mangrove hanya dapat dimanfaatkan sebagai kayu bakar oleh pesanggem.

Hampir semua nilai rataan indikator persepsi pesanggem mengenai fungsi sosial ekonomi tergolong rendah, hanya hutan mangrove dapat dijadikan saraan rekreasi saja yang tinggi. Hal ini karena terdapat hutan wisata di Desa Sedari hasil kerjasama LMDH Mina Wana Lestari, pesanggem, dan Pemerintah Desa Sedari.

\section{Partisipasi pada Tahap Perencanaan Pengelolaan Tambak Mangrove Model Empang Parit}

Sebagian besar pesanggem memiliki partisipasi rendah pada tahap perencanaan pengelolaan tambak mangrove ramah lingkungan model empang-parit. Sebesar 52,85 persen (37 orang) pesanggem memiliki partisipasi rendah pada tahap perencanaan. Sementara itu, sebesar 47,15 persen (33 orang) pesanggem memiliki partisipasi tinggi pada tahap perencanaan. Hal ini terjadi karena memang dalam tahap perencanaan, pesanggem hampir tidak diberi ruang oleh Perum Perhutani untuk berpartisipasi. Mereka hanya diinformasikan tentang naskah perjanjian dan 
melaksanakannya.

Nilai rataan indikator partisipasi dalam tahap perencanaan pengelolaan tambak mangrove model empang-parit yang tergolong rendah adalah keikutsertaan dalam setiap pertemuan, penentuan luas rabak, penentuan spesies tanaman payau yang ditanam, penentuan waktu pelaksanaan kegiatan, dan penentuan sanksi. Sementara itu, indikator partisipasi dalam tahap perencanaan yang tergolong tinggi adalah penentuan pengurus LMDH Mina Wana Lestari, penentuan luas tambak, penentuan luas parit (wilayah memelihara ikan di empang), penentuan jenis ikan yang dibudidayakan, dan penentuan sistem bagi hasil (sharing).

\section{Partisipasi pada Tahap Pelaksanaan Pengelolaan Tambak Mangrove Model Empang Parit}

Sebagian besar pesanggem memiliki partisipasi tinggi pada tahap pelaksanaan pengelolaan tambak mangrove model empang parit. Sebesar 65,71 persen (46 orang) pesanggem memiliki partisipasi tinggi pada tahap pelaksanaan. Sementara itu, sebesar 34,29 persen (24 orang) pesanggem memiliki partisipasi rendah pada tahap pelaksanaan.

Nilai rataan indikator partisipasi responden pada tahap pelaksanaan tambak mangrove ramah lingkungan model empang-parit yang tergolong rendah adalah pemberantasan organisme pengganggu tanaman payau. Sementara itu, nilai rataan indikator partisipasi responden pada tahap pelaksanaan yang tergolong tinggi adalah penyulaman tanaman payau yang mati, pencegahan/pelarangan perlakuan yang merusak/mematikan tanaman payau, dan pembayaran bagi hasil kepada pihak pertama sesuai kesepakatan awal.

Hasil dari kuesioner bertolak belakang dengan fakta yang sebenarnya dimana menurut beberapa informan, pesanggem memiliki partisipasi rendah terutama pada saat pelaksanaan pengelolaan tambak mangrove model empang-parit. Selain itu, sepanjang pengamatan Peneliti di lapangan memang pesanggem memiliki partisipasi rendah pada tahap pelaksanaan terlihat dari banyak tanaman payau di tambak tidak terawat dan mati.

\section{Partisipasi pada Tahap Monitoring Pengelolaan Tambak Mangrove Model Empang Parit}

Sebagian besar pesanggem memiliki partisipasi rendah pada tahap monitoring pengelolaan tambak mangrove model empang parit. Sebesar 71,43 persen (50 orang) pesanggem memilki partisipasi rendah. Sementara itu, sebesar 28,57 persen (20 orang) pesanggem memiliki partisipasi tinggi. Hal ini karena memang masih terdapatnya jarak antara pesanggem dengan Perum Perhutani. Pesanggem cenderung takut apabila memberikan laporan kepada Perum Perhutani berkaitan dengan masalah dalam pengelolaan tambak dan mereka berpikir bahwa kegiatan pengelolaan tambak mangrove ini lebih merupakan tanggung jawab Perum Perhutani dibandingkan mereka.

Hampir semua nilai rataan indikator partisipasi responden pada tahap monitoring/evaluasi pengelolaan tambak mangrove ramah lingkungan model empang-parit tergolong rendah. Hanya pemantauan terhadap jalannya kegiatan tambak dan pelaporan masalah yang terjadi dalam pengelolaan tambak kepada LMDH saja yang nilai rataannya tergolong tinggi.

\section{Partisipasi Tahap Menikmati Hasil Pengelolaan Tambak Mangrove Ramah Lingkungan Model Empang Parit}

Sebagian besar pesanggem memiliki partisipasi tinggi pada tahap menikmati hasil pengelolaan tambak mangrove model empang parit. Sebesar 75,71 persen (53 orang) pesanggem memiliki partisipasi tinggi pada tahap menikmati hasil. Sementara itu, sebesar 24,29 persen (17 orang) memiliki partisipasi rendah pada tahap menikmati hasil. Hal ini memang karena pesanggem menyadari bahwa pembagian andil tambak kepada mereka cukup adil, tergantung kemampuan membayar uang sharing. Selain itu, tidak ada pungutan lain dalam pengelolaan tambak mangrove selain dari uang sharing. Semua nilai rataan indikator partisipasi pesanggem pada tahap menikmati hasil pengelolaan tambak mangrove model empang parit tergolong tinggi.

\section{Hubungan Antara Persepsi Mengenai Hutan Mangrove dengan Partisipasi dalam Pengelolaan Tambak Mangrove Model Empang Parit}

Dapat dilihat pada Tabel 1 bahwa hanya satu hubungan yang signifikan, yaitu hubungan antara persepsi pesanggem mengenai fungsi ekologi mangrove dengan partisipasi pesanggem pada tahap monitoring pengelolaan tambak mangrove model empang parit. Hal ini diduga karena responden yang memiliki persepsi negatif mengenai fungsi ekologi hutan mangrove tidak percaya bahwa tujuan dari pengelolaan tambak mangrove adalah melestarikan mangrove untuk mencegah bencana alam ditambah lagi hubungan yang tidak akrab dengan Perum Perhutani sehingga responden akan curiga dan lebih mengawasi jalannya kegiatan tambak mangrove.

Secara umum persepsi pesanggem mengenai hutan mangrove dengan partisipasi pesanggem dalam pengelolaan tambak mangrove model empang parit tidak berhubungan. Hasil ini berbeda dengan penelitianpenelitian sebelumnya. Susiatik (1998), Haryanto (2003), Zulfarina (2003), Erwina (2005), Kholiq (2009), dan Amrijono (1993) mengemukakan bahwa persepsi berhubungan dengan partisipasi masyarakat. Namun demikian dalam penelitian ini, persepsi dan partisipasi masyarakat tidak berhubungan. Perbedaan hasil penelitian ini dengan penelitian sebelumnya, diduga karena beberapa hal, yaitu:

1) Perbedaan lokasi penelitian, metodologi, serta karakteristik populasi dan sampel penelitian yang digunakan.

2) Perbedaan pihak-pihak yang berkepentingan dalam pengelolaan sumberdaya alam dimana penelitian dilakukan. Mengambil contoh yang paling relevan, yaitu penelitian Haryanto (2003) dan Erwina (2005). Pada penelitian Haryanto (2003) dan Erwina (2005), model pengelolaan sumberdaya alam berbasis masyarakat. Sementara itu dalam penelitian ini, model pengelolaan sumberdaya alam bersifat top down dimana Perum Perhutani memiliki wewenang penuh

100 Elhaq, Imam Habibi. et. al. Persepsi Pesanggem Mengenai Hutan Mangrove dan Partisipasi Pesanggem dalam Pengelolaan Tambak Mangrove Ramah Lingkungan Model Empang Parit. 
dalam pengelolaan tambak dan pesanggem tidak diberi ruang untuk berpartisipasi aktif, terutama pada tahap perencanaan.

\section{Analisis Kepentingan dalam Pengelolaan Tambak Mangrove Model Empang Parit}

Partisipasi adalah keikutsertaan pemangku kepentingan dalam setiap tahapan kegiatan pembangunan dari mulai perencanaan, pelaksanaan, monitoring, hingga menikmati hasil. Pemangku kepentingan yang teridentifikasi dalam pengelolaan tambak mangrove model empang parit di Desa Sedari adalah pesanggem, Perum Perhutani, dan Pemerintah Desa Sedari. Setiap pemangku kepentingan tersebut memiliki kepentingan masing-masing dalam pengelolaan tambak mangrove yang harus dapat berjalan bersama-sama.

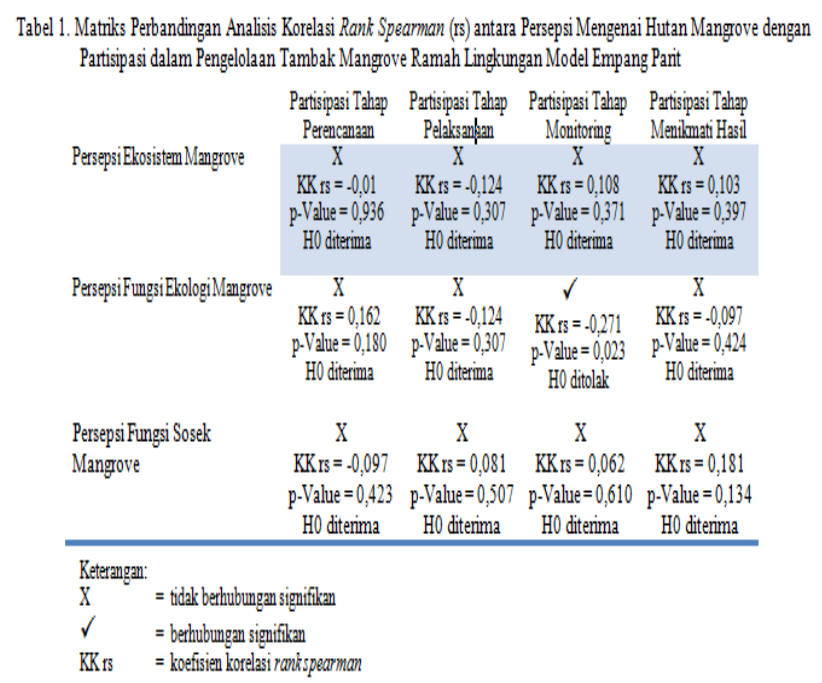

Pesanggem memiliki kepentingan utama dalam pengelolaan tambak mangrove untuk mencari penghasilan ekonomi. Sebagian besar pesanggem bergantung pada memelihara ikan dan udang di tambak untuk mendapatkan penghasilan, Pesanggem sebenarnya juga memiliki kepentingan untuk melestarikan mangrove dalam pengelolaan tambak mangrove. Namun, pesanggem lebih mengutamakan mengelola tambak agar dapat memenuhi kebutuhan hidup sehari-hari.

Perum Perhutani memiliki kepentingan utama dalam pengelolaan tambak mangrove untuk mendapatkan keuntungan ekonomi dan melestarikan mangrove. Keuntungan ekonomi yang didapat oleh Perum Perhutani berasal dari uang sharing yang didapatkan dari pesanggem tetapi uang tersebut sebagian digunakan untuk memelihara anakan bakau yang akan ditanam pada tambak mangrove. Walaupun begitu, tidak terdapat transparansi aliran uang sharing (bagi hasil) yang dibayarkan pesanggem dalam pengelolaan tambak sehingga menimbulkan kecurigaan di antara pesanggem dan Pemerintah Desa Sedari.

Pemerintah Desa Sedari memiliki kepentingan utama dalam pengelolaan tambak mangrove sebagai pelindung dari LMDH Mina Wana Lestari. Pemerintah Desa Sedari juga berperan sebagai pihak tengah yang mengawasi jalannya pengelolaan tambak mangrove agar anggota LMDH mendapat hak-haknya. Kepentingan lain dari
Pemerintah Desa Sedari adalah melestarikan mangrove agar Desa Sedari terhindar dari berbagai bencana alam seperti banjir, tsunami, abrasi, dan erosi. Selain itu, Pemerintah Desa Sedari juga memiliki kepentingan ekonomi dari pengelolaan tambak karena mendapat beberapa bagian dari pembayaran pesanggem yang uang tersebut selanjutnya digunakan untuk pembangunan infrastruktur Desa Sedari.

Pengelolaan tambak mangrove ramah lingkungan model empang parit merupakan suatu bentuk pengelolaan sumberdaya alam dimana di dalamnya terdapat kepentingan pesanggem, Perum Perhutani, dan Pemerintah Desa Sedari. Berbagai kepentingan beberapa pihak dalam pengelolaan sumberdaya alam sebenarnya dapat dianalisis menggunakan pendekatan dalam ekologi politik, yaitu pendekatan aktor.

Terjadi pertarungan kepentingan antara pesanggem, Perum Perhutani, dan Pemerintah Desa Sedari dalam pengelolaan tambak mangrove untuk akses dan kontrol terhadap tambak mangrove. Pesanggem membutuhkan tambak mangrove untuk mencukupi kebutuhan ekonominya, Perum Perhutani untuk mendapatkan keuntungan ekonomi dan memelihara tanaman payau, sementara itu Pemerintah Desa Sedari untuk mengawasi jalannya pengelolaan tambak mangrove agar pesanggem mendapat hak-haknya, memelihara mangrove, dan memperoleh uang sharing untuk pembangunan desa. Masing-masing pihak memiliki kepentingannya yang berbeda sehingga apabila bertemu dan tidak dikelola dengan baik, maka akan timbul masalah dalam pengelolaan tambak mangrove.

Terlihat jelas dalam pengelolaan tambak mangrove model empang parit di Desa Sedari bahwa terdapat ketidaksetaraan kekuasaan antara pesanggem, Perum Perhutani, dan Pemerintah Desa Sedari. Perum Perhutani jelas memiliki kekuasaan paling besar dalam pengelolaan tambak mangrove. Perum Perhutani berhak menentukan sistem pengelolaan tambak, anggota LMDH Mina Wana Lestari yang mengelola tambak beserta luas garapannya (walaupun memang Perum Perhutani tidak pernah membatasi), dan proporsi bagi hasil dalam pengelolaan tambak. Pesanggem dalam pengelolaan tambak mangrove ini hanya memiliki hak pakai tambak dimana mereka harus membayar uang sharing yang telah ditentukan dan terikat peraturan-peraturan yang dibuat oleh Perum Perhutani. Pemerintah Desa Sedari hampir tidak memiliki kekuasaan dalam pengelolaan tambak mangrove dimana posisi pemerintah desa sebagai pelindung LMDH Mina Wana Lestari dan hanya berperan dalam mengawasi jalannya kegiatan tambak mangrove secara umum. Selain itu, pemerintah desa hanya menerima sebagian kecil dari profit pengelolaan tambak mangrove.

Salah satu poin penting dalam partisipasi, yaitu pemangku kepentingan yang terlibat memiliki kekuasaan dan pengaruh yang sama dalam kegiatan pembangunan, tidak terdapat dalam pengelolaan tambak mangrove ramah lingkungan model empang parit. Ketidaksetaraan kekuasaan antara pesanggem, Perum Perhutani, dan Pemerintah Desa Sedari dalam pengelolaan tambak mangrove model empang parit menyebabkan partisipasi 
pesanggem menjadi rendah. Pesanggem hampir tidak diberikan ruang untuk menentukan sistem pengelolaan tambak dan berpartisipasi aktif pada tahap perencanaan. Pesanggem merasa bahwa kegiatan pembangunan ini bukanlah miliknya, tetapi milik Perum Perhutani sehingga sebagian besar pesanggem hanya mengelola tambak untuk memenuhi kebutuhan sehari-hari (jangka pendek) tanpa melestarikan mangrove di tambak (untuk kepentingan jangka panjang). Manfaat ekologi tidak didapat karena mangrove tidak lestari dan semakin tercemar akibat sisasisa limbah pengelolaan tambak. Sementara itu, manfaat ekonomi terutama bagi pesanggem dengan luas tambak sempit tidak didapat karena sering terjadi banjir dan kualitas air yang buruk.

Perum Perhutani memiliki kewenangan penuh dalam penentuan sistem pengelolaan tambak mangrove. Peraturan dan sanksi hanya dikenakan kepada pesanggem dan itupun ditentukan oleh Perum Perhutani. Padahal seharusnya ada juga peraturan dan sanksi bagi Perum Perhutani apabila melakukan pelanggaran dalam pengelolaan tambak mangrove. Walaupun terlihat setiap pemangku kepentingan mendapatkan haknya, sebenarnya yang paling diuntungkan secara ekonomi adalah Perum Perhutani. Hal ini karena pesanggem mendapatkan keuntungan dari hasil panen yang tidak menentu dan pemerintah desa mendapatkan hanya sebagian kecil dari uang bagi hasil, yaitu Rp10.000/ha/tahun. Sementara itu, Perum Perhutani mendapatkan Rp77.200/ha/tahun untuk tambak kelas II, Rp94.000/ ha/tahun untuk tambak kelas III, dan Rp144.400/ha/tahun untuk tambak kelas IV. Hal ini tentunya menimbulkan kesenjangan ekonomi antara pemangku kepentingan yang apabila tidak dicari solusinya akan menimbulkan konflik.

Dapat dilihat pada Gambar 1 mengenai relasi antara pemangku kepentingan dalam pengelolaan tambak mangrove ramah lingkungan model empang-parit di Desa Sedari. Hubungan antara pesanggem dengan pemerintah Desa Sedari menggambarkan hubungan alliance (kerjasama), sementara itu hubungan antara Perum Perhutani dengan pesanggem dan Perum Perhutani dengan pemerintah desa menggambarkan hubungan konflik. Hubungan antara pesanggem dengan pemerintah desa memang baik karena pemerintah desa selalu membela hak-hak pesanggem dan pesanggem juga berkontribusi dalam pembangunan desa. Hubungan Perum Perhutani dengan pesanggem dan Pemerintah Desa Sedari sejak dahulu memang tidak baik terutama tahun 1970-an saat belum dibentuk LMDH Mina Wana Lestari.

Kondisi pengelolaan tambak mangrove di Desa Sedari saat ini belum menggambarkan suatu pengelolaan sumberdaya alam yang tepat. Hal ini karena terlihat jelas perbedaan kekuasaan antara pemangku kepentingan dan kesenjangan ekonomi yang terjadi dimana Perum Perhutani lebih superior dari pesanggem dan Pemerintah Desa Sedari. Menurut Satria (2009), peran pemerintah sebagai agen dan pelindung sumberdaya perairan tidak jarang menimbulkan konflik dengan masyarakat. Pemerintah menggunakan instrumen kebijakan dengan menetapkan suatu wilayah sebagai kawasan konservasi. Wilayah pengelolaan tambak mangrove seluas 2.840,95 ha merupakan wilayah yang ditetapkan Departemen
Kehutanan sebagai kawasan hutan dimana Perum Perhutani diberikan wewenang untuk mengelolanya. Penetapan hutan mangrove Desa Sedari menjadi kawasan sebenarnya telah mengeliminasi hak-hak pesanggem dan Pemerintah Desa Sedari untuk mengakses dan mengontrol penuh sumberdaya alam Desa Sedari. Pengelolaan yang tidak tepat dan hanya menguntungkan satu pihak saja akan menimbulkan konflik nyata dalam pengelolaan mangrove Desa Sedari di masa depan.

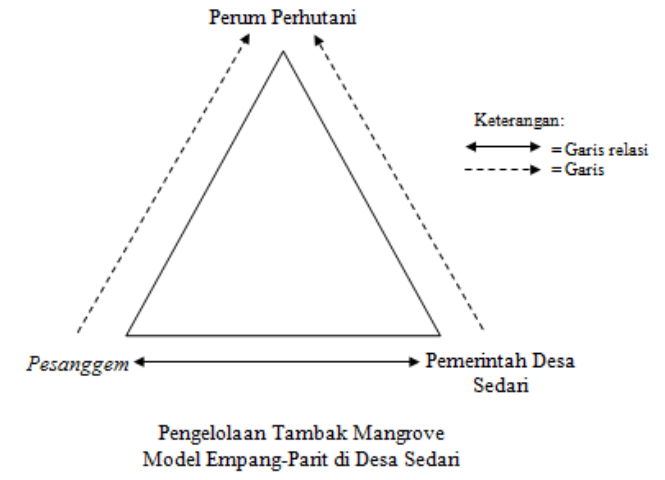

Gambar.1, Relasi antara PemangkuKepentingandalamPengelolaan Tambak Mangrove Model Empang-Parit di Desa Sedan

\section{KESIMPULAN DAN SARAN}

\section{Kesimpulan}

Sebagian besar pesanggem memiliki persepsi positif mengenai ekosistem hutan mangrovedan fungsi ekologi hutan mangrove. Sebagian besar pesanggem memiliki persepsi negatif mengenai fungsi sosial-ekonomi hutan mangrove. Sebagian besar pesanggem memiliki partisipasi rendah pada tahap perencanaan dan tahap monitoring pengelolaan tambak mangrove. Sebagian besar pesanggem memiliki partisipasi tinggi pada tahap pelaksanaan dan tahap menikmati hasil pengelolaan tambak mangrove.

Hasil analisis korelasi rank spearman hanya mendapatkan satu hubungan yang signifikan, yaitu hubungan antara persepsi pesanggem mengenai fungsi ekologi mangrove dengan partisipasi pesanggem dalam pengelolaan tambak mangrove ramah lingkungan model empang parit. Sementara itu, yang lainnya tidak berhubungan signifikan.

Partisipasi pesanggem dalam pengelolaan tambak mangrove ramah lingkungan model empang-parit di Desa Sedari yang tergolong rendah ini tentunya berdampak pada pengelolaan tambak mangrove ramah lingkungan di Desa Sedari. Salah satu masalah yang timbul sebagai dampak dari partisipasi pesanggem yang kurang adalah banyak tanaman payau yang ditanam di tambak pesanggem tidak terawat dan akhirnya mati. Sementara itu, hasil panen tambak yang didapat pesanggem dari tahun ke tahun semakin berkurang terutama akibat kualitas air yang semakin buruk karena pencemaran air yang tidak dapat dibendung karena hutan mangrove yang rusak. Hal ini tentunya jauh dari tujuan utama pengelolaan tambak mangrove model empang-parit yang menciptakan suatu pengelolaan hutan mangrove yang dapat mengakomodir baik fungsi ekologi maupun fungsi sosial-ekonomi bagi masyarakat sekitar hutan. Oleh karena itu, dibutuhkan perbaikan dalam pengelolaan 
tambak mangrove model empang-parit di Desa Sedari diperoleh partisipasi aktif setiap pihak terutama pesanggem sehingga terwujud pengelolaan hutan mangrove yang dapat mengakomodir kepentingan ekologi dan sosial ekonomi masyarakat yang berkelanjutan.

\section{Saran}

Beberapa hal yang menurut Peneliti harus diperbaiki dalam pengelolaan tambak mangrove model empang parit di Desa Sedari, yaitu: (1) diikutsertakannya pesanggem secara aktif dalam perancangan program; (2) tenaga pelaksana teknis dari Perum Perhutani di lapangan yang lebih banyak; (3) bersama-sama antara pesanggem dan Perum Perhutani membangun suasana akrab (kekeluargaan) agar pesanggem terbuka mengemukakan masalah-masalah yang dihadapi; (4) komunikasi dua arah dalam pengelolaan tambak agar pesanggem lebih aktif dalam tahap monitoring/evaluasi; (5) proaktif dari Perum Perhutani terhadap masalah-masalah yang dihadapi pesanggem; (6) profitabilitas yang lebih tinggi bagi para pesanggem; (7) uang sharing yang harus dibayarkan oleh pesanggem tidak terlalu besar dan disesuaikan dengan kondisi panen yang didapatkan; (8) pelatihan-pelatihan budidaya tambak kepada para pesanggem dengan tujuan meningkatkan produktivitas tambak mereka; (9) kerelaan dari para pesanggem untuk berkorban waktu dan tenaga memelihara tanaman payau di tambak dan lingkungan desa; (10) dukungan aktif dari pihak pemerintah Desa Sedari secara terus menerus dalam pengelolaan tambak mangrove.

\section{DAFTAR PUSTAKA}

Amrijono, Djoko. 1993. "Persepsi, Sikap, dan Partisipasi Masyarakat dalam Upaya Memasyarakatkan Taman Lingkungan di Kompleks Perumahan Kekancan Mukti di Kotamadya Semarang”. Tesis. Program Pasca Sarjana Universitas Gadjah Mada.

Anonymous. 2000. "Dampak Perkembangan Industri Tambak Udang Terhadap Ekosistem Pesisir dan Hutan Mangrove di Indonesia". Makalah Dialog Nasional. Tidak dipublikasikan.

Atkinson, Rita L., Richard C. Atkinson, Ernest R. Hilgard. 1983. Pengantar Psikologi, Edisi kedelapan Jilid I, Alih bahasa: Dra. Nurdjannah Taufiq, Dra. Rukmini Barhana. Editor: Agus Dharma, SH, M. Ed. Ph. D, Michael Adryanto. Jakarta. Erlangga.

Dahuri, M., J.Rais, S.P. Ginting, M.J. Sitepu. 1996. Pengelolaan Sumber Daya Wilayah Pesisir Secara Terpadu. Jakarta. PT. Pradnya Paramita.

Erwina. 2005. "Analisis Persepsi dan Partisipasi Masyarakat Terhadap Kualitas Lingkungan di Daerah Pesisir: Kasus Kelurahan Marunda, Jakarta Utara". Tesis. Program Pasca Sarjana Institut Pertanian Bogor.

Haryadi, Ceppy. 1995. "Kelimpahan Sampah Padat di Hutan Lindung Mangrove Angke Kapuk DKI Jakarta". Skripsi. Fakultas Kehutanan Institut Pertanian Bogor.
Haryanto, Bambang. 2003. "Kajian Persepsi Masyarakat Lokal dalam Upaya Pengelolaan TambakMangrove Terpadu di Desa Pematang Pasir, Kecamatan Ketapang, Lampung Selatan, lampung. Tesis. Program Pasca Sarjana Institut Pertanian Bogor.

IUCN. 1993. Ecology and Management of Mangroves, Bangkok. Thailand: Dyna Print Ltd. Part.

Kholiq. 2009. "Persepsi dan Partisipasi Masyarakat dalam Pengembangan Lumbung Pangan di Kabupaten Lampung Barat”. Tesis. Program Pasca Sarjana Institut Pertanian Bogor.

Leavitt, Harold J. 1978. Psikologi Manajemen: Sebuah Pengantar Bagi Individu dan Kelompok di dalam Organisasi. Jakarta. Erlangga.

Makmur, Setia. 2005. "Partisipasi Masyarakat dalam Program Pengembangan Prasarana Pedesaan (P2D)". Skripsi. Departemen Ilmu-ilmu Sosial Ekonomi Pertanian Fakultas Pertanian, Institut Pertanian Bogor.

Murdiyanto, Bambang. 2003. Mengenal, Memelihara, dan Melestarikan Ekosistem Bakau. Jakarta: COFISH Project.

Nybakken, J.W. 1992. Biologi Laut Suatu Pendekatan Ekologis. Terjemahan. Jakarta. PT. Gramedia.

Satria, Arif. 2009. Pesisir dan Laut Untuk Rakyat. Bogor. IPB Press.

Singarimbun, M, Sofian Effendi. 1989. Metode Penelitian Survai. Jakarta: PT. Pustaka LP3ES Indonesia, anggota IKAPI.

Susiatik, Titik. 1998. "Persepsi dan Partisipasi Masyarakat Terhadap Kegiatan Pembangunan Masyarakat Desa Hutan Terpadu (PMDHT) di Desa Mojorero, Kecamatan Wirosari, Kabupaten Dati II Grobogan, Jawa Tengah". Tesis. Program Pasca Sarjana Institut Pertanian Bogor.

Witjaksono, Julian. 2002. "Struktur Komunitas Mangrove dan Analisis Finansial Usaha pada Lahan Konversi Hutan Mangrove di Pesisir Teluk Kendari”. Tesis. Program Pasca Sarjana Institut Pertanian Bogor.

Zimbardo, Philip G. 1975. Psychology and Life, Edisi kesembilan. United States of America. Scott, Foresman Company.

Zulfarina. 2003. "Persepsi dan Partisipasi Petani terhadap usaha pertanian konservasi (Studi Kasus Kelompok Pengelola Hutan Kemasyarakatan di Kawasan Hutan Lindung Register 45B, Kabupaten Lampung Barat, Provinsi Lampung”. Tesis. Program Pasca Sarjana Institut Pertanian Bogor. 